\title{
A Brief History of Record Management at the National Archives
}

Paul Rock

What follows is a much abridged version of a section of the opening chapter of the official history of criminal justice between 1959 and 1997 which David Downes, Tim Newburn and I were formally commissioned to write some six and a half years ago. Our work has been based on numerous archives, secondary sources and interviews, but the principal resource, and the principal archive, the repository of government records, the 'strong box of the Empire', is the National Archive at Kew, and it is on record management there that I shall dwell.

One thing that struck us almost immediately, and struck us by surprise, was that whole areas of criminal justice history that might have been documented in that archive are now blank and irretrievable. Over and over again, we stumbled upon voids in the historical evidence, and we all too often found ourselves floundering and foundering. Thus, although the papers of all Royal Commissions and many interdepartmental committees are meticulously preserved, the material that must once have documented the deliberations that initiated them, and the material that documented their consequences, may no longer remain. There are no files in the Home office relating to Michael Williams, the prisoner whose incarceration in Wakefield control unit in 1974 caused a furore which led to their closure; none on the decision taken in 1929 to appoint a Select Committee on capital punishment, and none on what government made of it; none on the decision to appoint the Wolfenden Committee, and none on what government made of it; none on the Home Secretary's decision to accede to representations made in support of an appeal against the conviction of three young men for the death of Maxwell Confait, 
none on the Royal Commission on Criminal Procedure that stemmed from the appeal, and none on the establishment of the CPS that flowed from the Royal Commission. And so it goes on. So much has been lost.

It accordingly seemed sensible to take an expedition to explore how it came about that record-keeping in the latter half of the twentieth century seemed to have been organised as much by a desire to destroy materials as to preserve them. It offers an interesting small exercise in the sociology of knowledge, examining how the past can be made visible, ${ }^{i}$ and what follows is a much abridged and simplified account of why so many records have been lost over the years.

The predecessor of the National Archives, the Public Record Office, had been founded in 1838 as part of a Benthamite State-building project. It housed not only papers stretching back to the beginnings of record-keeping, but also the flow of documents continuously generated by an increasingly energetic state. It was a flow that came into time to clog up and overwhelm not only the PRO but also the Government departments which generated it, and officials were at a loss about what to do.

The Archives fell constitutionally under the supervision of the Master of the Rolls, the second most senior judge in England and Wales, and, as his name suggested, the keeper of the rolls. But their active management during the 1940s and 1950s, a critical period, was entrusted to a deputy keeper, Sir Hilary Jenkinson, acknowledged to be the chief authority on record-keeping practice in the English-speaking world. It was his firm contention that the role of the archivist was solely to receive and conserve the documents that were entrusted to him by administrators, that their decision about what to submit should be sovereign, and that he could not and should not exercise any discretion in the 
matter of selection, because the archivist's discretion would inevitably reflect ephemeral prejudices. Historians, too, were deemed to be ill-equipped to judge the possible future value of materials offered for deposit in Chancery Lane because scholarly tastes and interests would inevitably shift in unpredictable fashion.

The outcome was simple. In the period up to and during the Second World War, especially, documents began to pile up in what seemed to be uncontrollable fashion. There was a continual resort to ad hoc measures. Records were housed under a so-called 'Limbo' scheme in emergency storage, in deep shelters at London Underground stations, and in specially adapted buildings at Hayes and Yeading. It was never enough. It was that pressure of volume which formed the immediate propellant of change. But there were four other triggers as well:

a) One of our predecessors, Professor Sir William Hancock, the Director of the Institute of Commonwealth Studies at the University of London, reported in the 1950 Webb Memorial Lecture, 'The History of our Times', that 12,000,000 files of war records in the Board of Trade alone were awaiting the record managers' attention. They were expected to require 16 miles of shelving; existing procedures simply would not be able to cope; ;i and the fearsome logistical and economic implications of what lay ahead alarmed Whitehall. iii 'Think', Sir William warned, 'of what is coming to the Public Record Office!'iv What he said was noted and reported by senior Treasury officials responsible for funding and answering politically for the PRO. 
b) Officials also noted and reported the 'alarm expressed by the [1949] Hoover Commission v on the unwieldy size of public records'vi in the United States', an alarm that led to a radical organisational restructuring of record management in Washington. The parallels were clear.

c) Treasury officials were exercised by the findings of a relatively new organisation and methods team that had as a result been despatched in 1951 to inquire into the affairs of the PRO. There was what a PRO official called 'the very alarming state of affairs revealed by the information produced by Departments in response to a questionnaire ... 'vii

d) And officials were spurred on by the Prime Minister, Sir Winston Churchill, who, at yet another time of financial austerity, declared himself appalled at plans to spend £300,000 in 1952 (equivalent to some $£ 8,226,000$ at 2015 prices) on filing

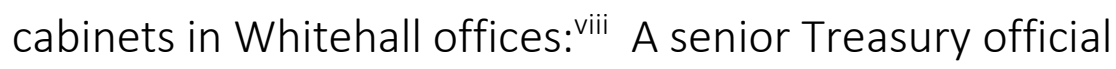
recorded that 'This led the Prime Minister to suggest that we ought to devote more attention to destroying old papers so as to avoid the demand for a lot of new filing equipment. I was happy to be able to tell the Prime Minister that we had in mind the appointment of a Committee to consider this business of records. It is clear that the Prime Minister would like this dealt with as a matter of urgency and at a rather high level'. ix

A committee was indeed appointed, under the chairmanship of a dyspeptic Sir James Grigg, a former Permanent Secretary at the War Department, and supported by Treasury officials. One thing that the 
Treasury was intent on from the first was the exclusion of Sir Hilary Jenkinson, a man whose archaic ideas were thought to have engendered and sustained the crisis of an unsustainable flood of paper, and whose sense of authority and personal grandeur were unsupportable. Sir Edward Bridges, the permanent secretary, in charge of establishing the committee, said of one preparatory meeting in early January 1952 that he was, 'obviously going to be extremely difficult to deal with. He was touchy and acid to a degree. He was resentful of the O. \& M. investigation. He says that he is the world authority on the subject and that everything will be simple if only his methods are adopted at once'. His colleague, Edward Playfair, concurred: concurred, and I hope those of a sensitive disposition will not be shocked by the language I am about to quote. Sir Hilary, he said, was an 'old mountain of prejudice', 'a real cough-drop.... he talks incessantly and is perfectly convinced that he knows all the answers'. The committee would have 'the most awful time $^{\prime x}$ if Sir Hilary were allowed to join it. And if Sir Hilary were excluded, so, it was argued, should every other civil servant from the PRO.

The Grigg committee was consequently bereft of archival experts. Its emphasis was not on how to choose, house and preserve records. It was on how to destroy them. A pressing crisis demanded a pressing solution, and the committee's formal terms of reference would be to 'review the arrangements for the preservation of the records of Government departments ... in the light of the rate at which they are accumulating and of the purposes which they are intended to serve'. ${ }^{\mathrm{i}} \quad$ Its conclusion was not unpredictable. There was, it said, a manifest and urgent need to reduce the volume of records that could and should be saved. 'Few of 
these', it declared, 'will need to be preserved, but their very number greatly complicates the process of deciding which should be preserved, and which destroyed' xii The Master of the Rolls, Lord Evershed, would later recall in a memorandum to the Lord Chancellor:

'There are in the Public Record Office about 40 miles of Records covering the whole period of English history. The quantity of documents now in Government Departments awaiting sorting and transfer and representing about 50 years only of administration is said to amount to about $1 \frac{1}{2}$ times the whole content of the Public Record Office.... The problem of Departmental Records having assumed such proportions that it was in danger of reaching administrative breakdown, the "Grigg Committee" ... was appointed by the present Chancellor of the Exchequer and myself' . xii

The solutions propounded had little to do with the historical value of records. That was not the issue. An eager commentator pronounced in the archival profession's own mouthpiece, the Journal of the Society of Archivists, that 'The report rightly assumes that a large proportion of the documents created in a department should be destroyed as of no value to anybody. Those that are kept must be worthy of the endless trouble and expense that their retention will entail - valuable accommodation, equipment, cleaning, preservation and repairs through the centuries. Selection must be drastic ... riv And with no little irony, the Secretary of the Committee could cite Sir Hilary's own magnum opus, the Manual of Archive Administration, to the effect historians and archivists were incapable of assessing historical value.

The ensuing 1958 Public Records Act, ${ }^{x v}$ enacted at the very opening of our period and still in force whilst we worked, xvi transferred the management of the public records to the Lord Chancellor, who, as head 
of the judiciary, was thought best equipped to assume responsibility for legal records;:xvii and a newly-created Keeper of the Public Records, assisted by an Advisory Council on Public Records, who would be required to sift through 'mountains of records', xviii and not only decide which were to be retained but also control what Theodore Plucknett, Professor of Legal History at the London School of Economics, and a former chairman of the Master of the Rolls Archives Committee, called the officials' 'dangerous power of destruction'. ${ }^{\text {xix }}$ Closely following the proposals of the Grigg Committee, the Act introduced a system of internal Departmental reviews to examine which records should continue to be retained, and stated merely, under Sec. 3(1), that 'It shall be the duty of every person responsible for public records of any description which are not in the Public Record Office or a place of deposit appointed by the Lord Chancellor under this Act to make arrangements for the selection of those records which ought to be permanently preserved and for their safe-keeping', provided only that, under Sec. 3(2) 'Every person shall perform his duties under this section under the guidance of the Keeper of Public Records and the said Keeper shall be responsible for co-ordinating and supervising all action taken under this section'.

Government ministries were in their turn to appoint a suitable internal official, a Departmental Records Officer, ${ }^{x x}$ to take charge of their papers, review them five years after they had 'passed out of active use' (para. 80) and then destroy those which were no longer needed ${ }^{\mathrm{xxi}}$ (and the first such officers were nominated in May 1956 - there were to be officers in post in 64 Departments by the end of the next year). Any records not thus discarded were to be reviewed again after 25 years, and those 
deemed no longer to be of historical or administrative importance were to be destroyed (para. 87). Records that did succeed in passing that second muster were to be kept only if they were thought still to be of administrative use, and the remainder were to be sent for safekeeping to the Public Record Office (although the criteria for identifying historical importance were not clearly identified at the time). That was not to be the end of the matter. Attrition could continue. The archivists of the Public Record Office were obliged to keep their own stock of documents under 'continuous review' and, in consultation with the relevant Departments, dispose of those which were thought no longer to justify retention.

Only latterly, and as guidelines for departmental record officers crystallised, did criteria for the identification of the public importance of records emerge, and that was after Jenkinson had quit the PRO. The new principles seemed to embody a process that had been formulated in Washington by Theodore Schellenberg, Jenkinson's rival for the leadership of the archival world. The 1971 guidelines issued, for instance, a series of 'general descriptions of the main kinds of records which are likely to merit selection for permanent preservation at the Public Record Office... ', and they included papers which:

'1a. Show the reasons for important actions or decisions

b. Provide a precedent for future actions or decisions

c. Are a guide to possible action should a similar set of circumstances arise in the future...

e. Contain important policy decisions ... 
2. Records relating to-

a. The setting-up, proceedings and reports of committees, working parties and study groups;

b. Important decisions on policy...

k. Subjects of interest nationally or internationally ... ixxii

But, it must be repeated, the prime concentration always appeared to be on destruction. 98\% of government papers never reach TNA (the image conventionally invoked was that for every 100 miles of shelving filled by government files each year, TNA could receive only 1 mile). Take figures supplied to us by the Home Office for 1989, the last year in which such an inventory was taken: 1379 feet of files had been examined at first review, 370 of which - or some $27 \%$ - were destroyed, and 225 feet, or $16 \%$ were retained for second review. 1202 feet of policy files - or 95\% - were destroyed, and 35 feet - or 3\% - were then selected for the PRO at second review. No doubt much that is lost is of little or no value, but the lacunae that the three of us continually encountered are there, and some of them are baffling indeed.

\footnotetext{
i There is, to be sure, a very broad history of records management by Elizabeth Shepherd, Archives and archivists in 20th century England ((2009) Farnham: Ashgate), but it contains none of the detail offered in this chapter.

ii 'Time', he said, 'does his weeding through the agency of officials working by rules. ... ' Insufficiently valuable documents were to be destroyed, but 'Unfortunately, the criteria of value are variable and subjective'. And the task had grown to such proportions that 'I doubt whether the old procedures of the Public Record Office can cope with it. . . Some of the most precious grain of war-historical record never got into the registered files and may therefore never come to the Public Record Office: conversely, in the registered files of the war period there are tares by the million; but good wheat is mingled with the tares. How can they be separated?' 'The History of our Times', The Webb Memorial Lecture, 1950, London: The Athlone Press, pp.
} $8-9$.

iii Note to Edward Playfair, Public Records, 28 ${ }^{\text {th }}$ December 1951, Treasury file OM68/3/01

iv $\quad$ Ibid, p. 8. 
$\mathrm{v}$ Hoover Commission on the Organization of the Executive Branch of the Government (1949) Report, New York: McGraw-Hill. The Commission reported on pp. 78 and 80 that 'the maintenance of records costs the Federal Government enormous sums annually. The records now in existence would fill approximately six buildings each the size of the Pentagon. In 1948, some 18 million square feet of space were filled with records. Our task force estimates that, on the basis of rental value alone, the space costs for this volume of records is at least 20 million dollars annually'. And the number of records was increasing alarmingly, from $5 \mathrm{~m}$ cubic feet in 1933 , to $10 \mathrm{~m}$ in 1938 and over $15 \mathrm{~m}$ in 1944 . Its recommendation was that there should be a new Records Management Bureau in the Office of General Services; a new Federal Records Management Law to provide for the more effective preservation, management, and disposal of Government records; and an 'adequate records management program in each department and agency' (p. 80).

vi Indecipherable, note to Mr Simpson, $29^{\text {th }}$ November 1951, Examination of the Workings of Public Records Acts, Treasury file OM68/3/01

vii J. Collingridge; 'Implementing the Grigg Report', Journal of the Society of Archivists, op. cit., p. 179. The report revealed that the 53 departments consulted housed some 1,100,000 linear feet of records not still in current use but not yet old enough to be reviewed for destruction; and 300,000 linear feet of records awaiting possible destruction, of which it was estimated that 50,000 would be passed to the PRO for preservation. The Treasury inquiry into the PRO was only one of a number conducted at the time. Others included the Tate Gallery, the Wallace Collection, the National Maritime Museum and the British Museum.

viii His Ministry was responsible for the installation and maintenance of services in the various buildings occupied by the PRO.

ix Sir Edward Bridges to Mr Simpson, $21^{\text {st }}$ December 1951, Treasury file OM68/3/01.

x Note to Sir Edward Bridges, 1 February 1952, Treasury file OM68/3/01.

xi The Times, $28^{\text {th }}$ June 1952.

xii Committee on Departmental Records, Report, op. cit., pp. 5-6.

xiii Memorandum, Public Record Office and the Grigg Report, undated, PRO 1445

xiv P. Jones, 'The Grigg Report', op. cit., p. 7.

xv The Public Records Act 1958, Chapter 51: An Act to make new provision with respect to public records and the Public Record Office, and for connected purposes.

xvi See http://www.nationalarchives.gov.uk/documents/information-management/best-practice-guideappraising-and-selecting.pdf which states that 'For over 50 years public records bodies have followed the system of appraisal established by the Grigg Report in 1954.'

xvii Notes for Supplementaries, draft statement for the Prime Minister, $1^{\text {st }}$ July 1955, PREM 11 911. The Master of the Rolls wrote to Sir James on the $29^{\text {th }}$ November 1955 to say that 'One reason which, I confess, much influenced me (and I think Bridges also) was the position of the Legal Records. It seemed to me that any difficulties of segregation would be best dealt with if the Lord Chancellor were Head of All Records. . . . ' PJGG10(2) Churchill Archives Centre, Cambridge. The decision had been taken against Sir James' advice. He told the Master of the Rolls 'As you know I was not consulted with the Treasury decided to make the Lord Chancellor the Minister responsible for departmental records and I do not agree with the decision'. Note to, $12^{\text {th }}$ March 1957, PJGG10(2) Churchill Archives Centre, Cambridge.

xviii See T. Plucknett; 'The Public Records Act 1958', The Modern Law Review, Vol. 22, No. 2 (March 1959), p. 182.

xix Ibid

$\mathrm{xx} \quad$ The prime duty of the Officer was described as being 'to ensure that his function is as widely known within his department as possible and, in particular, that he is regarded as the authoritative, natural source of advice on any matters connected with records'. Manual of Records Administration, Public Record Office, February 1983, 2.1.3.

xxi The first reference in the files to the proposed new system was an anonymous note, dated the 25 October 1952, which made no allusion to the origin of the scheme other than to 'the various ideas on this subject that have been ventilated in discussion and elsewhere'. Treasury file OM68/6/09.

xxii Reproduced in P. Hennessy; 'Whitehall guidelines on preservation of documents are made public', The Times, $7^{\text {th }}$ March 1978. 